\title{
A CRITICAL ANALYSIS OF STUDIES ASSESSING L-ORNITHINE-L-ASPARTATE (LOLA) IN HEPATIC ENCEPHALOPATHY TREATMENT
}

\author{
Patrícia Coelho de SOÁREZ1', Ana Cláudia OLIVEIRA², Jorge PADOVAN', \\ Edison Roberto PARISE² and Marcos Bosi FERRAZ
}

\begin{abstract}
Context - Experimental and clinical studies suggest that LOLA may have a favorable influence on hepatic encephalopathy due to the effect on the reduction of ammonia, and improvement of the symptoms and laboratory findings. Objectives - To evaluate and to critically analyze the efficacy and/or effectiveness results of the use of LOLA when compared to placebo in the treatment of hepatic encephalopathy. Data sources - LILACS, SciELO, MEDLINE, PubMed database and Cochrane Collaboration Register of Controlled Trials were searched from 1966 to September of 2006. The review has included all the randomized controlled double-blind clinical trials performed in humans in English language. Results - Four studies published between 1993 and 2000 were selected and reviewed. LOLA was showed as being able to reduce hyperammonemia in patients with hepatic encephalopathy, when compared to patients in the placebo group. Conclusions - Although the trials have shown efficacy of LOLA in reducing hyperammonemia of hepatic encephalopathy, sufficient evidence of a significant beneficial effect of LOLA on patients with hepatic encephalopathy was not found. The studies performed in this area were small, with short follow-up periods and half of them showed low methodological quality. HEADINGS - Hepatic encephalopathy. Dipeptides.
\end{abstract}

\section{INTRODUCTION}

Change in the brain function is a characteristic complication of acute or chronic liver failure. In addition to the traditional presentation, as frank hepatic encephalopathy (HE), a subclinical manifestation form is currently known, where the patient has a normal neurological status, but manifests motor and cognitive deficits detected only by specific tests ${ }^{(50)}$. Minimum hepatic encephalopathy (MHE) is an entity of unquestionable clinical importance due to the high prevalence, occurring in up to $84 \%$ of cirrhotic patients. Furthermore, MHE may potentially evolve to frank HE in about $56 \%$ in 3 years ${ }^{(47)}$ negatively interfering in the survival of these individuals. This survival is not bigger than $20 \%$ in 5 years, following the identification of the clinically manifested disease.

In spite of a silent course, studies have shown that daily activities $^{(70)}$ and quality of life ${ }^{(16)}$ of cirrhotic individuals with MHE are compromised. Use of lactulose in the treatment MHE was related to improvement in the detection tests of the disease, in addition to the impact in the quality of life ${ }^{(47)}$ of these individuals; however, its routine usage in the clinical practice is questionable and more prospective, randomizes trials are necessary.
Most of therapeutic measures currently in use aim the reduction of serum levels of ammonia, principally through a smaller production of enteric ammonia. Experimental and clinical trials, started more than 25 years ago, suggest that L-ornithine L-aspartate (LOLA) may have a favorable influence on HE due to the effect on the reduction of ammonia, and improvement of symptoms and laboratory findings related to $\mathrm{HE}$.

However, few controlled trials are known to have reached theses results, as the possibility of spontaneous resolution without specific therapeutics is known. As there is a current lack of consensus related to the usage of LOLA in HE, the present study has the purpose of evaluating and critically analyzing efficacy and/ or effectiveness studies of the use of LOLA when compared to placebo in the treatment of HE.

\section{METHODS}

\section{Criteria for consideration of studies in this review \\ Type of studies}

The review has included all the randomized controlled double-blind clinical trials performed

São Paulo Center for Health Economics, CPES, Federal University of São Paulo, Brazil; ${ }^{2}$ Department of Gastroenterology, Federal University of São Paulo, Brazil. Correspondence: Dr. Patrícia Coelho de Soárez - Rua Botucatu, 685 - Vila Clementino - 04023-062 - São Paulo, SP, Brazil. E-mail: patricia.soarez@cpes.org.br 
in humans and published in indexed journals, in English language. Material published as abstracts, news, and letters to the editor or presentations in congress were not included.

\section{Type of participants}

Patients with cirrhosis, hyperammonemia, and HE, any gender, age or ethnicity were included.

\section{Type of intervention}

Experimental intervention could be LOLA dosed by oral or parenteral route in any dosage or duration. Control group could be a placebo.

\section{Searching strategy for identification of the studies}

A comprehensive searching strategy was formulated, in order to identify all the relevant studies. LILACS, SciELO and MEDLINE (1966-9/2006) were searched, by using the following terms: "ornithine" and "aspartate" and ("hepatic encephalopathy"). PubMed (1966-9/2006) was searched, by using the terms "L-ornithine-L-aspartate" or "ornithine-aspartate". Cochrane Collaboration Register of Controlled Trials (CCRCT) was also searched, by using the term "ornithine".

\section{Critical analysis of the papers}

The methodological quality of the papers included was evaluated according to the following schedule ${ }^{(17)}$ :

a. Was the patient allocation randomized?

b. Were all the patients who took part in the trial properly evaluated?

i Was the follow-up complete?

ii Were the patients analyzed according to the randomization?

c. Were the patients, health professionals and researchers blinded?

d. Were the groups similar in the beginning of the trial, except for the intervention?

e. Were the groups equally followed-up?

f. What were the results?

i How large was the effect of the treatment?

ii How accurate was the estimation of the effect of the treatment?

g. Can the results help in the treatment of my patients?

i Can the results be applied to my patients?

ii Were all the clinically important outcomes considered in the trial?

iii Are the probable benefits of the treatment worth the potential costs and hazards?

Evaluation of the methodological quality of the studies was finished by using JADAD et al. ${ }^{(26)}$ scale, composed by three items, quantifying the probability of bias related to the trial according to the description of randomization, masking, withdrawals and drop outs. Scores vary from 1 to 5; studies that present scores 1 or 2 are considered as showing low quality and studies that present scores 3 to 5 are considered as showing high quality.

\section{RESULTS}

\section{Search results}

A total of 271 references was identified by electronic search in MEDLINE ( $\mathrm{n}=22)$, PubMed $(\mathrm{n}=97)$ and Cochrane Collaboration Register of Controlled Trials $(n=152)$. No paper was found in LILACS and SciELO database. Fifty nine duplicate references and 145 references considered as irrelevant after reading the abstracts were excluded.

From the remaining 67 references, 63 were excluded, 16 reviews $^{(5,6,7,12,13,27,28,31,32,38,44,51,56,67,69,72)}, 1$ letter to the editor ${ }^{(33)}$, 7 abstracts ${ }^{(21,29,39,40,46,53,55)}, 1$ presentation in congress ${ }^{(34)}, 14$

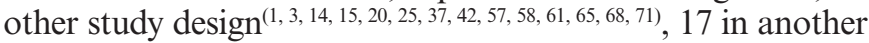
language $(2,4,8,9,10,19,24,35,43,45,48,52,59,60,62,66,73)$ and 7 clinical trials that have not met our inclusion criteria ${ }^{(11,18,22,23,36,41,49)}$. Remaining references are four randomized, controlled clinical trials that met the inclusion criteria ${ }^{(30,54,63,64)}$. Figure 1 shows the results from the search and Figure 2 describes the included studies.

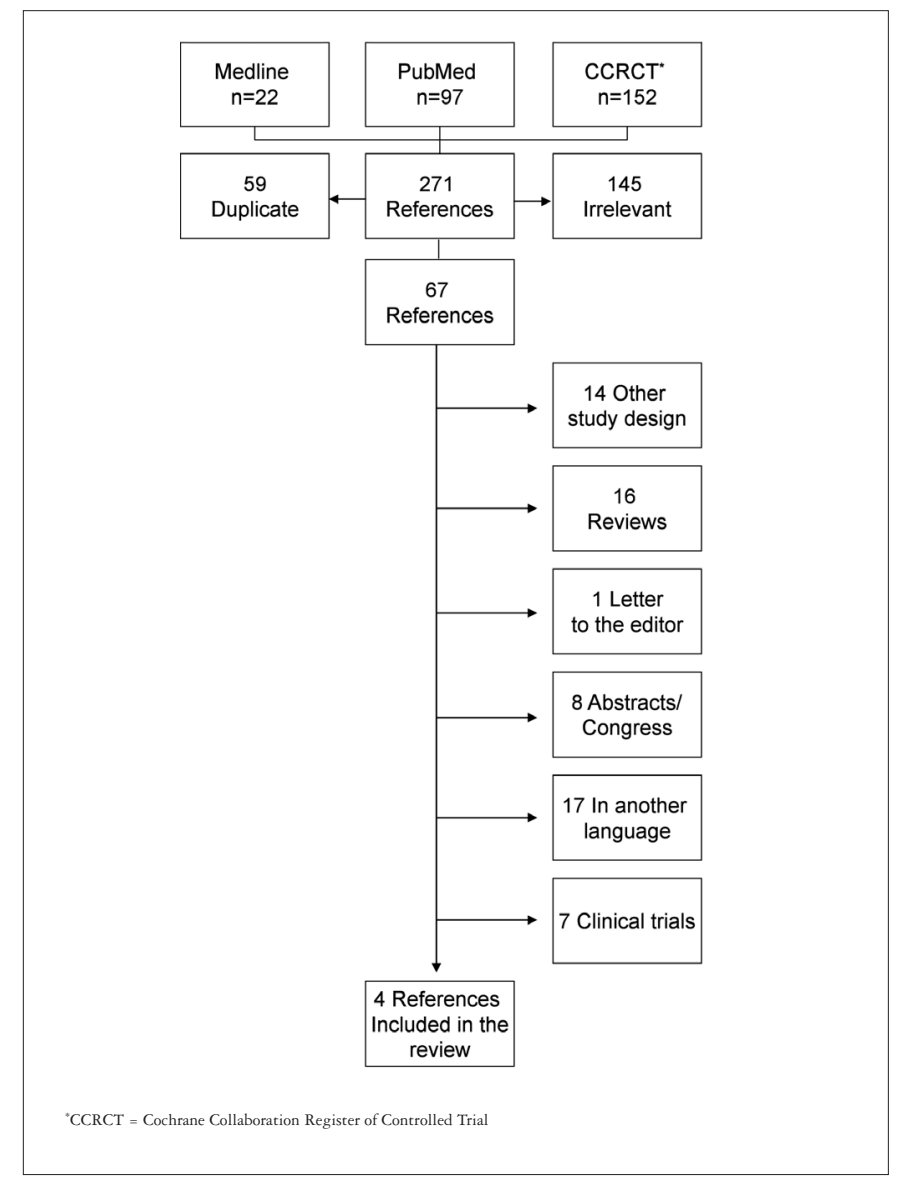

FIGURE 1. Choice of studies for review

\section{Description of the studies}

Four trials were included in this analysis. All four trials were reviewed as complete papers. Details of the trials were described in Figure 2. Two trials used parallel groups design and two trials used crossover groups design. 


\begin{tabular}{|c|c|c|c|}
\hline Studies & Year & Objective & Reason for inclusion \\
\hline Rees CJ et al. ${ }^{(54)}$ & 2000 & $\begin{array}{l}\text { To evaluate the effect of } \\
\text { LOLA in healthy subjects } \\
\text { with cirrhosis and without } \\
\text { evidence of clinical } \\
\text { encephalopathy following } \\
\text { dosing of oral glutamine }\end{array}$ & $\begin{array}{l}\text { Randomized, controlled, } \\
\text { two-fold crossover, double- } \\
\text { blind, placebo controlled } \\
\text { clinical trial }\end{array}$ \\
\hline Stauch S et al. ${ }^{(64)}$ & 1998 & $\begin{array}{l}\text { To investigate the } \\
\text { therapeutical efficacy of } \\
\text { LOLA in patients with } \\
\text { cirrhosis, hyperammonemia } \\
\text { and frank, stable, chronic } \\
\text { HE, and MHE }\end{array}$ & $\begin{array}{l}\text { Randomized, controlled, } \\
\text { double-blind, placebo } \\
\text { controlled clinical trial }\end{array}$ \\
\hline Kircheis G et al. ${ }^{(30)}$ & 1997 & $\begin{array}{l}\text { To investigate the } \\
\text { therapeutical efficacy of } \\
\text { LOLA in patients with } \\
\text { cirrhosis, hyperammonemia } \\
\text { and chronic, persistent HE. }\end{array}$ & $\begin{array}{l}\text { Randomized, controlled, } \\
\text { double-blind, placebo } \\
\text { controlled clinical trial }\end{array}$ \\
\hline Staedt $\mathrm{U}$ et al. ${ }^{(63)}$ & 1993 & $\begin{array}{l}\text { To evaluate the effects } \\
\text { of LOLA in plasma } \\
\text { concentration of ammonia } \\
\text { and amino acids from } \\
\text { patients with cirrhosis }\end{array}$ & $\begin{array}{l}\text { Randomized, controlled, } \\
\text { four fold crossover, double- } \\
\text { blind, placebo controlled } \\
\text { clinical trial }\end{array}$ \\
\hline
\end{tabular}

$\mathrm{HE}=$ Hepatic encephalopathy

FIGURE 2. Studies included characteristics and reasons for inclusion

A total of 217 patients were randomized in the trials. Mean number of patients in each trial was 54 (varying from 10 to 126). Mean ages varied from 52 to 57 in these trials. All 217 patients had cirrhosis. The etiology of cirrhosis was alcohol $(81 \%)$, hepatitis $(14 \%)$, and others $(5 \%)$. Patients had some kind of hepatic encephalopathy (three trials), minimum hepatic encephalopathy (two trials) and grade I and II hepatic encephalopathy (two trials). (Table 1)

TABLE 1. Description of the patients according to the trial included

\begin{tabular}{|c|c|c|c|c|c|}
\hline Patients & $\begin{array}{c}\text { REES } \\
\text { et al. (2000) } \\
(54) \\
\mathrm{n}(\%)\end{array}$ & $\begin{array}{c}\text { STAUCH } \\
\text { et al. (1998) } \\
(64) \\
\mathrm{n}(\%)\end{array}$ & $\begin{array}{c}\text { KIRCHEIS } \\
\text { et al. (1997) } \\
(30) \\
\mathrm{n}(\%)\end{array}$ & $\begin{array}{c}\text { STAEDT } \\
\text { et al. (1993) } \\
\text { n (63) } \\
\text { n } \%)\end{array}$ & n $(\%)$ \\
\hline $\begin{array}{l}\text { Total number of } \\
\text { patients (n) }\end{array}$ & 15 & 66 & 126 & 10 & 217 \\
\hline Male & NA & $42(64)$ & $91(72)$ & $8(80)$ & $141(70)^{*}$ \\
\hline Female & NA & $24(36)$ & $35(28)$ & $2(20)$ & $61(30)^{*}$ \\
\hline $\begin{array}{l}\text { Age (years) } \\
\text { (mean) }\end{array}$ & 52 & 57 & 57 & 53 & 55 \\
\hline $\begin{array}{l}\text { Cirrhosis } \\
\text { etiology } \\
\text { Alcohol } \\
\text { Hepatitis } \\
\text { Other }\end{array}$ & $\begin{array}{c}14(93) \\
1(7) \\
0(0)\end{array}$ & $\begin{array}{c}54(82) \\
8(12) \\
4(6)\end{array}$ & $\begin{array}{c}100(79) \\
20(16) \\
6(5)\end{array}$ & $\begin{array}{l}8(80) \\
2(20) \\
0(0)\end{array}$ & $\begin{array}{c}176(81) \\
31(14) \\
10(5)\end{array}$ \\
\hline $\begin{array}{l}\text { HE Grade } \\
0 \\
\text { MHE } \\
\text { I } \\
\text { II }\end{array}$ & $\begin{array}{l}0(0) \\
0(0) \\
0(0) \\
0(0)\end{array}$ & $\begin{array}{c}0(0) \\
23(35) \\
25(38) \\
18(27)\end{array}$ & $\begin{array}{c}0(0) \\
53(42) \\
53(42) \\
20(16)\end{array}$ & $\begin{array}{c}0(0) \\
0(0) \\
3(30) \\
0(0)\end{array}$ & $\begin{array}{c}0(0) \\
76(35) \\
81(37) \\
38(17)\end{array}$ \\
\hline $\begin{array}{l}\text { Child-Pugh } \\
\text { Grade } \\
\text { A } \\
\text { B } \\
\text { C } \\
\end{array}$ & $\begin{array}{c}0(0) \\
12(80) \\
3(20)\end{array}$ & $\begin{array}{c}38(58) \\
21(32) \\
7(10)\end{array}$ & $\begin{array}{l}64(51) \\
50(40) \\
12(9)\end{array}$ & NA & $\begin{array}{l}102(49)^{* * *} \\
83(40)^{* * *} \\
22(11)^{* * *}\end{array}$ \\
\hline $\begin{array}{l}\text { NA }=\text { Not available } \\
\mathrm{HE}=\text { Hepatic encepha } \\
\text { MHE = Minimum hep } \\
\text { "Number and percenta } \\
\text { " Number and percent }\end{array}$ & $\begin{array}{l}\text { hy } \\
\text { encephalopathy } \\
\text { om three trials tl } \\
\text { rom three trials t }\end{array}$ & $\begin{array}{l}\text { nformed patient } \\
\text { informed patien }\end{array}$ & $\begin{array}{l}\text { gender } \\
\text { Child-Pugh grade }\end{array}$ & & \\
\hline
\end{tabular}

With respect to the administration of ornithine-aspartate, three trials used parenteral dosing and one trial used oral dosing. Average amount of LOLA was $18 \mathrm{~g}$ /day (ranging from 5 to $40 \mathrm{~g}$ ) and mean duration of the treatment was 7 days (ranging from 2 to 14 days) (Table 2).

TABLE 2. Description of LOLA administration, control and additional therapy according to the trial included

\begin{tabular}{|c|c|c|c|c|}
\hline Studies & $\begin{array}{l}\text { Total } \\
\text { number of } \\
\text { patients }\end{array}$ & $\begin{array}{c}\text { Study medication/ } \\
\text { daily dosage/route of } \\
\text { administration/duration of } \\
\text { the treatment }\end{array}$ & $\begin{array}{l}\text { Number } \\
\text { of patients } \\
\text { included } \\
\text { in each } \\
\text { group }\end{array}$ & $\begin{array}{l}\text { Age (years) } \\
\text { Mean (SD) or } \\
\text { variation }\end{array}$ \\
\hline Rees et al. ${ }^{(53)}$ & 15 & $\begin{array}{c}\text { LOLA } 5 \mathrm{~g} / \mathrm{IV} \\
\text { Placebo/IV } \\
2 \text { days with } 1 \text { week-interval } \\
\text { between the infusions }\end{array}$ & $\begin{array}{l}15 \\
15\end{array}$ & $\begin{array}{l}52 \text { (NA) } \\
52 \text { (NA) }\end{array}$ \\
\hline Stauch et al. ${ }^{(64)}$ & 66 & $\begin{array}{c}\text { LOLA } 18 \mathrm{~g} / \text { oral } \\
\text { Placebo/oral } \\
14 \text { consecutive days }\end{array}$ & $\begin{array}{l}34 \\
32\end{array}$ & $\begin{array}{l}48.5(64.6) \\
70.9(74.1)\end{array}$ \\
\hline $\begin{array}{l}\text { Kircheis et } \\
\text { al. }{ }^{(29)}\end{array}$ & 126 & $\begin{array}{c}\text { LOLA } 20 \mathrm{~g} / \mathrm{IV} \\
\text { Placebo/IV } \\
7 \text { consecutive days }\end{array}$ & $\begin{array}{l}63 \\
63\end{array}$ & $\begin{array}{l}53.9(12.4) \\
52.3(13.3)\end{array}$ \\
\hline Staedt et al. ${ }^{(63)}$ & 10 & $\begin{array}{c}\text { LOLA } 5 \mathrm{~g} / \mathrm{IV} \\
\text { LOLA } 20 \mathrm{~g} / \mathrm{IV} \\
\text { LOLA } 40 \mathrm{~g} / \mathrm{IV} \\
\text { Placebo } 5 \mathrm{~g} / \mathrm{IV} \\
4 \text { days with } 2-5 \text { days- } \\
\text { interval between the } \\
\text { infusions }\end{array}$ & $\begin{array}{l}10 \\
10 \\
10 \\
10\end{array}$ & $\begin{array}{l}53(10) \\
53(10) \\
53(10) \\
53(10)\end{array}$ \\
\hline
\end{tabular}

IV $=$ Intravenous
LOLA = L-ornithi

LOLA $=$ L-ornithine-L-aspartate

$\mathrm{NA}=$ Not available

Placebo was used as comparator for LOLA in all four trials.

Ornithine aspartate administration was accompanied by special nutritive diets ( $0.8-1 \mathrm{~g}$ of protein $/ \mathrm{kg}$ of weight $/$ per day) in three trials. LOLA administration was accompanied by ingestion of $20 \mathrm{~g}$ of oral glutamine. Overall, LOLA group and control group received a similar caloric regimen in all four trials.

All four trials evaluated the improvement in the clinical outcomes caused by the use of LOLA. Clinical outcomes were analyzed by plasma concentration of ammonia postmeal and in fasting condition, plasma concentration of some amino acids, psychometric tests such as NCT-A, mental status grade, PSEI, CRT (patients' choice reaction time) and electroencephalogram. Figure 3 presents the effects of the use of LOLA.

\section{Results of critical analysis}

Even though the term "randomization" has been used in all four trials, only two studies reported the generation of the randomized allocation sequence and masking of the allocation.

Follow-up was complete in only two of the studies; intention to treat analysis was performed, and the patients were analyzed according to the randomization.

Two studies described the initial status of the groups (baseline), but with no statistical analysis, and hence proving that the two groups were actually comparable in all aspects was difficult. Homogeneity test with $P$-value would have been 


\begin{tabular}{|c|c|c|c|c|c|c|}
\hline Reference & $\begin{array}{l}\text { Plasma concentration } \\
\text { of ammonia }\end{array}$ & NCT-A & Mental status & PSEI & CRT & EEC \\
\hline Rees et al. ${ }^{(53)}$ & $\begin{array}{l}\text { In the patients without } \\
\text { TIPS: there was a } \\
\text { significant improvement } \\
\text { in LOLA-treated } \\
\text { patients. } \\
\text { In the patients with } \\
\text { TIPS: there was no } \\
\text { statistically significant } \\
\text { difference in LOLA- } \\
\text { treated patients }\end{array}$ & $\begin{array}{l}\text { In the patients without } \\
\text { TIPS and in the patients } \\
\text { with TIPS: there was no } \\
\text { statistically significant } \\
\text { difference in LOLA- } \\
\text { treated patients }\end{array}$ & $\mathrm{NA}$ & $\mathrm{NA}$ & $\begin{array}{l}\text { In the patients without } \\
\text { TIPS and in the patients } \\
\text { with TIPS: there was no } \\
\text { statistically significant } \\
\text { difference in LOLA- } \\
\text { treated patients }\end{array}$ & $\begin{array}{l}\text { In the patients without } \\
\text { TIPS and in the patients } \\
\text { with TIPS: there was no } \\
\text { statistically significant } \\
\text { difference in LOLA- } \\
\text { treated patients }\end{array}$ \\
\hline Stauch et al. ${ }^{(64)}$ & $\begin{array}{c}\text { There was a statistically } \\
\text { significant improvement } \\
\text { in LOLA-treated } \\
\text { patients }\end{array}$ & $\begin{array}{c}\text { There was a statistically } \\
\text { significant improvement } \\
\text { in LOLA-treated } \\
\text { patients }\end{array}$ & $\begin{array}{c}\text { There was a statistically } \\
\text { significant improvement } \\
\text { in LOLA-treated } \\
\text { patients }\end{array}$ & $\begin{array}{c}\text { There was a statistically } \\
\text { significant improvement } \\
\text { in LOLA-treated } \\
\text { patients }\end{array}$ & NA & $\mathrm{NA}$ \\
\hline Kircheis et al. ${ }^{(32)}$ & $\begin{array}{l}\text { In the subgroups HE I } \\
\text { and HE II: there was a } \\
\text { statistically significant } \\
\text { improvement in LOLA- } \\
\text { treated patients }\end{array}$ & $\begin{array}{l}\text { In all the subgroups } \\
\text { analyzed there was a } \\
\text { statistically significant } \\
\text { improvement in LOLA- } \\
\text { treated patients }\end{array}$ & $\begin{array}{l}\text { In the subgroups HE I } \\
\text { and HE II: there was a } \\
\text { statistically significant } \\
\text { improvement in LOLA- } \\
\text { treated patients }\end{array}$ & $\begin{array}{l}\text { In all the subgroups } \\
\text { analyzed there was no } \\
\text { statistically significant } \\
\text { improvement in LOLA- } \\
\text { treated patients }\end{array}$ & NA & $\mathrm{NA}$ \\
\hline Staedt et al. ${ }^{(63)}$ & $\begin{array}{l}\text { There was a significant } \\
\text { improvement only in the } \\
\text { patients treated with } 40 \\
\text { grams of LOLA }\end{array}$ & NA & $\mathrm{NA}$ & NA & NA & NA \\
\hline
\end{tabular}

CRT = Patients choice reaction time; $\mathrm{EEC}=$ Electroencephalogram;

FIGURE 3. Clinical parameters used to evaluate the effect of L-ornithine-L-aspartate compared to placebo

necessary in order to evaluate whether the difference among the groups was statistically significant.

Withdrawals and drop outs were described in only two of the studies. Ten patients (5\%) withdrew prematurely. Common reasons were lack of compliance to the treatment or adverse effects.

Report of any adverse effect occurred in seven patients $(3 \%)$, consisting of moderate gastrointestinal disorders, such as nausea and vomiting.

Quality was evaluated using Jadad scale, with scores varying from 1 to 5 . Five was the maximum value, higher quality, and 3 the minimum score of acceptable quality. Two of the selected papers presented score $2^{(54,63)}$, and the other two studies presented score $5^{(30,64)}$.

Figure 4 presents a summary of the critical analysis schedule and Jadad scale score from the studies analyzed.

\section{DISCUSSION}

Evaluation of efficacy of ornithine aspartate in reducing serum levels of ammonia and increasing neuropsychiatry status in HE has been studied during at least the last 3 decades. However, few double-blind, randomized, placebo-controlled clinical trials were able to detect such effect. Reduction of ammonia and improvement of encephalopathy clinical status, measured by psychometric tests (generally numeric connection test (NCT)) or mental status through the clinical scoring of encephalopathy has been the form of evaluating drug efficacy. Tolerance and the appearance of adverse effects shown by the patients have also been subject to evaluation in most of these studies.

Generally, the studies selected here showed that LOLA was able to reduce hyperammonemia in patients with

\begin{tabular}{|c|c|c|c|c|}
\hline Questions & $\begin{array}{l}\text { Rees et } \\
\text { al. } .^{(54)}\end{array}$ & $\begin{array}{l}\text { Stauch et } \\
\text { al. } .^{(64)}\end{array}$ & $\begin{array}{l}\text { Kircheis et } \\
\text { al. } .^{(30)}\end{array}$ & $\begin{array}{l}\text { Staedt et } \\
\text { al. }{ }^{(63)}\end{array}$ \\
\hline $\begin{array}{l}\text { Was the patient allocation } \\
\text { randomized? }\end{array}$ & Yes & Yes & Yes & Yes \\
\hline $\begin{array}{l}\text { Were all the patients who } \\
\text { took part in the trial properly } \\
\text { evaluated? } \\
\text { Was the follow-up } \\
\text { complete? } \\
\text { Were the patients } \\
\text { analyzed according to the } \\
\text { randomization? }\end{array}$ & No & Yes & Yes & No \\
\hline $\begin{array}{l}\text { Were the patients, health } \\
\text { professionals and researchers } \\
\text { masked? }\end{array}$ & Yes & Yes & Yes & Yes \\
\hline $\begin{array}{l}\text { Were the groups similar in } \\
\text { the beginning of the trial, } \\
\text { except for the intervention? }\end{array}$ & Yes & $\begin{array}{l}\text { Can not be } \\
\text { said }\end{array}$ & $\begin{array}{l}\text { Can not be } \\
\text { said }\end{array}$ & Yes \\
\hline $\begin{array}{l}\text { Were the groups equally } \\
\text { followed-up? }\end{array}$ & Yes & Yes & Yes & Yes \\
\hline \\
\hline $\begin{array}{l}\text { of the treatment? } \\
\text { How accurate was the } \\
\text { estimation of the effect of } \\
\text { the treatment? }\end{array}$ & $\begin{array}{l}\text { Can not be } \\
\text { said }\end{array}$ & $\begin{array}{l}\text { Can not be } \\
\text { said }\end{array}$ & $\begin{array}{l}\text { Can not be } \\
\text { said }\end{array}$ & $\begin{array}{c}\text { Can not be } \\
\text { said }\end{array}$ \\
\hline \multicolumn{5}{|l|}{$\begin{array}{l}\text { Can the results help in the } \\
\text { treatment of my patients? }\end{array}$} \\
\hline $\begin{array}{l}\text { Can the results be applied } \\
\text { to my patients? }\end{array}$ & Yes & Yes & Yes & Yes \\
\hline $\begin{array}{l}\text { Were all the clinically } \\
\text { important outcomes } \\
\text { considered in the trial? }\end{array}$ & Partially & Partially & Partially & Partially \\
\hline $\begin{array}{l}\text { Are the probable benefits } \\
\text { of the treatment worth } \\
\text { the potential costs and } \\
\text { hazards? }\end{array}$ & $\begin{array}{l}\text { Can not be } \\
\text { said }\end{array}$ & $\begin{array}{l}\text { Can not be } \\
\text { said }\end{array}$ & $\begin{array}{l}\text { Can not be } \\
\text { said }\end{array}$ & $\begin{array}{c}\text { Can not be } \\
\text { said }\end{array}$ \\
\hline Result of Jadad Scale & 2 & 5 & 5 & 2 \\
\hline
\end{tabular}

FIGURE 4. Summary of critical analysis of the papers included in the review 
HE, when compared to the group that used placebo. This reduction could be detected in the first hours following the infusion of intravenous drug (IV), in a crossover study with 10 cirrhotic patients from different etiologies. This finding was more pronounced when a higher dose of LOLA was used $(40 \mathrm{~g} /$ day) $(295 \times 216 \mathrm{mg} / \mathrm{dL}, P<0.005)$ and even more following diet with higher protein content $(0.5 \mathrm{~g} /$ $\mathrm{kg}$ /weight) in this same dosage ${ }^{(63)}$. In a bigger casuistic, with 126 cirrhotic patients, KIRCHEIS et al. ${ }^{(30)}$, observed significant reduction in serum ammonia on the $7^{\text {th }}$ day following the beginning of the IV infusion $(17 \pm 37 \mu \mathrm{mol}$ x $6 \pm 32 \mu \mathrm{mol}, P<0.05$ ), which was more expressive in the grade II encephalopathy subgroup than in the subclinical encephalopathy or grade I encephalopathy subgroup. This reduction was accompanied by improvement in the NCT-A performance and not necessarily by mental status measured by PSE index.

Efficacy measured in terms of reduction of circulating ammonia levels must be considered with caution. As seen before, there is no relation between this serum determination and the hepatic encephalopathy grade. Hence, there is a need for clinical parameters for this evaluation. On the other hand, numeric connection test, when used alone, do not represent a high sensitivity and specificity test in the evaluation of minimum and initial HE. During the last years, a number of psychometric tests and sensorial stimuli has been used, together or alone, and represent more sensitive forms to evaluate encephalopathy in these patients.

In these studies, different protein overloads were used in the induction of serum increase of ammonia, varying from 0.25 to $1 \mathrm{~g} / \mathrm{kg} /$ day. In addition, there were few references related to the origin of the protein, whether animal or vegetable, as differences in the ammoniogenic potential between them are known and possibly in the response to the treatment.

Oral drug efficacy was evaluated by STAUCH et al. ${ }^{(64)}$, in 1998 , considering a reduction in the bioavailability to $82.2 \% \pm 28 \%$. This study documented a progressive reduction in the level of ammonia through the 2 weeks of the study in both groups. However, this result was faster and more pronounced on the $14^{\text {th }}$ day of drug dosing in patients who used oral LOLA, when compared to values of the beginning of the study ( $40 \mu \mathrm{mol}$ x $60 \mu \mathrm{mol} ; P<0.001)$. This reduction in ammonia was also accompanied by improvement in NCT-A time (51 sec to $40 \mathrm{sec}$ ). The test was improved in 9 of 11 patients in MHE; one of the patients showed normalization of NCT-A time $(<30 \mathrm{sec})$. However, improvement in mental status was more enhanced in individuals with frank HE, where $79 \%$ showed improvement versus $40 \%$ in the placebo group, a non-detected difference in MHE. This difference in the behavior of MHE may be in the own definition of subclinical encephalopathy, where the patients do not show evident clinical manifestations of encephalic disease, making mental status evaluation difficult. On the other hand, higher drug dose and/or longer period of use might be necessary in this group.

In conclusion, the studies were able to demonstrate efficacy of LOLA in reducing hyperammonemia of HE, which was accompanied by improvement of the psychometric tests used; however, there might be the need for standardizing the amount and quality of the protein used in order to induce increase of ammonia in these cirrhotic patients, in addition to discussing and using more sensible HE detection tests, principally in the evaluation of MHE. There is a lack of trials with this drug in the more severe HE (grade II and III) compared, for instance, to a control group of patients, not without medication, but using standardized drugs and usually used in frank HE.

However, sufficient evidence of a significant beneficial effect of LOLA on patients with hepatic encephalopathy was not found. The trials performed in this area were small, with short follow-up periods and half of them showed low methodological quality.

We believe performing more randomized controlled clinical trials with solid design and methodology is necessary. All the trials must be reported according to the recommended guidelines (www.consort-statement.org).

Studies should include a greater number of patients and a longer follow-up period. Choice of more appropriate clinical parameters for evaluation of the drug effect such as combination of at least two psychometric tests, application of neurophysiologic tests in order to evaluate the visual (P100) or auditory (P300) evoked potential, magnetic resonance and spectroscopy to evaluate encephalic glutamine concentration, etc, has fundamental importance. Moreover, further outcome analyses which measure the improvement in the quality of life of these patients must be added in future studies. 
Soárez PC, Oliveira AC, Padovan J, Parise ER, Ferraz MB. Uma análise crítica dos estudos de avaliação do L-ornitina-L-aspartato (LOLA) no tratamento da encefalopatia hepática. Arq Gastroenterol. 2009;46(3):241-7.

RESUMO - Contexto - Estudos experimentais e clínicos sugerem que a L-ornitina-L-aspartato pode ter uma influência favorável na encefalopatia hepática em virtude do seu efeito na redução da amônia, e melhora dos sintomas e achados laboratoriais. Objetivos - Avaliar e analisar criticamente os estudos de eficácia e/ou efetividade do uso de L-ornitina-L-aspartato quando comparado com placebo no tratamento da encefalopatia hepática. Fontes de informação - Foram pesquisadas as bases de dados LILACS, SciELO, MEDLINE, PubMed e o Registro de Ensaios Controlados da Colaboração Cochrane no período de 1966 até setembro de 2006. A revisão incluiu todos os ensaios clínicos controlados randomizados, duplo-cego, em seres humanos, no idioma inglês. Resultados - Foram selecionados e revisados quatro estudos publicados entre 1993 e 2000, que mostraram que a L-ornitinaL-aspartato foi capaz de reduzir a hiperamonemia em portadores de encefalopatia hepática, quando comparados ao grupo que utilizou placebo. Conclusões - Embora os estudos tenham demonstrado eficácia da L-ornitina-L-aspartato em reduzir a hiperamonemia da encefalopatia hepática, não foi encontrada evidência suficiente que a L-ornitina-L-aspartato tenha um efeito clínico benéfico significativo em pacientes com encefalopatia hepática. Os ensaios realizados neste campo foram pequenos com períodos curtos de acompanhamento e a metade deles com baixa qualidade metodológica.

DESCRITORES - Encefalopatia hepática. Dipeptídeos.

\section{REFERENCES}

1. Albrecht J, Hilgier W, Januszewski S, Quack G. Contrasting effects of thioacetamideinduced liver damage on the brain uptake indices of ornithine, arginine and lysine: modulation by treatment with ornithine aspartate. Metab Brain Dis. 1996;11:22937.

2. Aschke J. Experiences with ornithine-aspartate in liver diseases. Med Welt. 1969;22:657-62.

3. Balestrieri C, De Cristofaro D, Cittadini D. Effect of ornithine-aspartate mixture on 15N-ammonia incorporation into urea in intact mice. Life Sci. 1967;6:337-40.

4. Because hepatic encephalopathy is a frequent contributing factor. Patients with liver cirrhosis are poorer drivers. MMW Fortschr Med. 2003;145:61.

Butterworth RF. Pathophysiology of hepatic encephalopathy: a new look at ammonia. Metab Brain Dis. 2002;17:221-7.

Butterworth RF. Brain edema in acute liver failure. Indian J Gastroenterol. 2003;22(Suppl 2):s59-61.

7. Butterworth RF. Role of circulating neurotoxins in the pathogenesis of hepatic encephalopathy: potential for improvement following their removal by liver assist devices. Liver Int. 2003;23(Suppl 3):5-9.

8. Chen MF, Li RC, Chen CH, Gao XC. [Therapeutic effect of L-ornithine-Laspartate on liver cirrhosis complicated by hepatic encephalopathy]. Di Yi Jun Yi Da Xue Xue Bao. 2005;25:718-9, 22.

9. Chronic liver diseases. Hepatic encephalopathy too frequently overlooked? MMW Fortschr Med. 2000;142:56-7.

10. Cirrhotic liver gives up in breaking up of ammonia. Poison for the brain. MMW Fortschr Med. 2004;146:51.

11. Delcker A, Turowski B, Mihm U, Raab P, Rusch O, Pilatus U, et al. Proton MR spectroscopy of neurometabolites in hepatic encephalopathy during L-ornithineL-aspartate treatment--results of a pilot study. Metab Brain Dis. 2002;17:103-11.

12. Desjardins $P$, Belanger M, Butterworth RF. Alterations in expression of genes coding for key astrocytic proteins in acute liver failure. J Neurosci Res. 2001;66:967-71.

13. Eisenburg J. Hepatic minimal encephalopathy. The most frequently overlooked, clinically occult "metabolic syndrome" on the cirrhosis patient. Fortschr Med. 1996;114:141-14. Finsterer J, Bernauer E. Recovery from Parkinson syndrome and prolonged visually evoked potentials in hepatic encephalopathy. Metab Brain Dis. 2005;20:55-60.

15. Gebhardt R, Beckers G, Gaunitz F, Haupt W, Jonitza D, Klein S, Scheja L. Treatment of cirrhotic rats with L-ornithine-L-aspartate enhances urea synthesis and lowers serum ammonia levels. J Pharmacol Exp Ther. 1997;283:1-6.

16. Groeneweg M, Quero JC, De Bruijn I, Hartmann IJ, Essink-bot ML, Hop WC, Schalm SW. Subclinical hepatic encephalopathy impairs daily functioning. Hepatology. 1998;28:45-9.

17. Guyatt GH, Sackett DL, Cook DJ. Users' guides to the medical literature. II. How to use an article about therapy or prevention. A. Are the results of the study valid? Evidence-Based Medicine Working Group. JAMA. 1993;270:2598-601.

18. Hartung HD. Amino acids prevent hepatic encephalopathy. Ornithine-aspartate in hyperammonemia--results of a study. Fortschr Med. 1989;107:56.

19. Hass HG, Nagele T, Seeger U, Hosl F, Gregor M, Kaiser S. Detection of subclinical and overt hepatic encephalopathy and treatment control after L-ornithine-L-aspartate medication by magnetic resonance spectroscopy ((1)H-MRS). Z Gastroenterol. 2005;43:373-8.

20. Henglein-Ottermann D. Influence of ornithine aspartate on the experimentally induced hyperammoniemia. Clinico-experimental study. Ther Ggw. 1976;115:150418.

21. Holm E, Hess Y, Leweling H, Barth H-O, Hagmüller E. Ornithine aspartate (OA) promotes amino acid (AA) retention in the peripheral tissues of patients with liver cirrhosis A double-blind randomized crossover study. JPEN J Parenter Enteral Nutr. 2000;15:368.

22. Hong Y, Yang ZB, Wang YF. Clinical control study of L-ornithine-L-aspartate in the treatment of subclinical hepatic encephalopathy. West China Med J. 2003;18:509-10.

23. Hunold W. Clinical experiences in liver diseases (especially in patients with fatty liver due to alcoholism and food poisoning) under monotherapy with ornithine aspartate. Z Allgemeinmed. 1973;49:469-72.

24. In liver cirrhosis, not every "ammonia lowering drug" improves neuropsychiatric deficit. MMW Fortschr Med. 2001;143(9):58.

25. Ito M, Matsumoto H, Kikuchi S, Yachi A. A comparative study of free amino acid levels in the serum and cerebral cortex in hepatic failure rats. No To Shinkei. 1986;38:63-8.

26. Jadad AR, Moore RA, Carroll D, Jenkinson C, Reynolds DJ, Gavaghan DJ, McQuay HJ. Assessing the quality of reports of randomized clinical trials: is blinding necessary? Control Clin Trials. 1996;17:1-12.

27. Jalan R, Seery JP, Taylor-Robinson SD. Review article. Pathogenesis and treatment of chronic hepatic encephalopathy. Aliment Pharmacol Ther. 1996;10:681-97.

28. Jalan R. Intracranial hypertension in acute liver failure: pathophysiological basis of rational management. Semin Liver Dis. 2003;23:271-82.

29. Kircheis G, Metz M, Frey S, Seiller E. Correlation between pharmacokinetic aspects and clinical efficacy of L-ornithine-L-aspartate (OA): results of randomized, controlled clinical trials. J Hepatol. 1996;25(Suppl 1):s131.

30. Kircheis G, Nilius R, Held C, Berndt H, Buchner M, Görtelmeyer R, Hendricks R, Krüger B, Kuklinski B, Meister H, Otto HJ, Rink C, Rösch W, Stauch S. Therapeutic efficacy of L-ornithine-L-aspartate infusions in patients with cirrhosis and hepatic encephalopathy: results of a placebo-controlled, double-blind study. Hepatology. 1997;25:1351-60.

31. Kircheis G, Haussinger D. Management of hepatic encephalopathy. J Gastroenterol Hepatol. 2002;17(Suppl 3):s260-7.

32. Kircheis G, Wettstein M, Dahl S, Haussinger D. Clinical efficacy of L-ornithineL-aspartate in the management of hepatic encephalopathy. Metab Brain Dis. 2002; 17:453-62.

33. Kleef R, Scheller A. L-ornithine aspartate - a rationale for its use in combination with chemotherapy, radiation, and hyperthermia in oncology. Forsch Komplementarmed. 1999;6:216.

34. Koczorek M. Chronic liver diseases. The nihilism has gone. MMW Fortschr Med. 2001;143(51/52):14.

35. Kosozu K. Clinical study on the effects of L-ornithine-L-aspartate on liver dysfunction. Iryo. 1966;20:339-46.

36. Kowalski P, Bieniecki M. Pharmacokinetics and bioavailability study of L-ornithineL-aspartate in healthy volunteers--a comparative study of two oral formulations. J Pharm Biomed Anal. 2006;41:1061-4. 
37. Kowalski P, Bieniecki M, Oledzka I, Lamparczyk H. Validated method for L-ornithine-L-aspartate analysis in human plasma by capillary electrophoresis. Biomed Chromatogr. 2006;20:185-94.

38. Kruger B, Held C, Kircheis G. Ornithine aspartate in hepatic encephalopathy: an established new therapeutic approach. Overview and results of current randomized studies. Z Arztl Fortbild (Jena). 1994;88:673-9.

39. Lang I, Feher J, Gogl A, Varga L, Varga L, Pronai L, Werling K. Ammonialowering effect of ornithine-aspartate infusion in cirrhotic patients with hepatic encephalopathy. Gut. 1994;35(Suppl 4):s158.

40. Leweling H, Gladisch R, Staedt U, Wolters U, Holm E. Effects of ornithine aspartate (OA) on plasma ammonia and plasma amino acids (AA) in patients with liver cirrhosis. A double-blind, randomized study using a four-fold crossover design. Hepatology. 1990;10(Suppl 1):s13.

41. Maev IV, V'Iuchnova E S, Lebedeva EG, Iakovenko EI, Dicheva DT. The response to combined therapy of hepatic encephalopathy in patients with hepatic cirrhosis. Klin Med (Mosk). 2002;80:42-5.

42. Maneesh M, Jayalekshmi H. Effect of ascorbic acid, alpha-tocopherol, lecithin and L-ornithine-L-aspartate on ethanol induced hypoproteinemia and hyperlipidemia in rats. Indian J Physiol Pharmacol. 2005;49:422-6.

43. Melzer H, Weber D, Wotzka R. On the therapy of liver diseases with ornithine aspartate. Med Klin. 1969;64:1541-4.

44. Mullen KD. Newer aspects of hepatic encephalopathy. Indian J Gastroenterol. 2003;22(Suppl 2):s17-s20.

45. Nakamura $\mathrm{H}$, Ishikawa $\mathrm{M}$. Effect of ornithine-aspartate on fecal excretion of mevalonate metabolites and the reticuloendothelial system. Igaku To Seibutsugaku. 1971;83:213-5.

46. Nilius R, Kircheis G. Improvement of hepatic encephalopathy (HE) in cirrhotic patients by treatment with L-ornithine-L-aspartate $(\mathrm{OA})$ infusion concentrate. Results of a placebo-controlled, double-blind clinical trial. J Hepatol. 1992;16(Suppl 1):s39.

47. Ortiz M, Jacas C, Cordoba J. Minimal hepatic encephalopathy: diagnosis, clinical significance and recommendations. J Hepatol. 2005;42(Suppl 1):s45-s53.

48. Perinovic M, Robovic Z, Grujic M, Ljubojevic S. Personal experiences in the treatment of internal diseases with ornithine aspartate. Med Arh. 1969;23(3):2932.

49. Podymova SD, Bueverov AO, Nadinskaia M. The treatment of hepatic encephalopathy with Hepa-Mertz. Ter Arkh. 1995;67(6):45-7.

50. Quero JC, Schalm SW. Subclinical hepatic encephalopathy. Semin Liver Dis 1996;16:321-8.

50. Quero Guillen JC, Carmona Soria I, García Montes JM, Jíménez Sáenz M, Herrerías Gutiérrez JM. Hepatic encephalopathy: nomenclature, pathogenesis and treatment. Rev Esp Enferm Dig. 2003;95:135-42, 127-34.

52. Raab W. Confirmation of a liver-protecting action of L-ornithine-L-aspartate using the experimental model of hypokalaemic liver damage. Wien Klin Wochenschr. 1972;84:348-9.

53. Rees CJ, Oppong K, Al-Mardini H, Hudson M, Rose J. The effect of L-OrnithineL-asparate on tips patients undergoing glutamine challenge. Eur J Gastroenterol Hepatol. 1996;8(Suppl 5):s16.

54. Rees CJ, Oppong K, Al Mardini H, Hudson M, Record CO. Effect of L-ornithineL-aspartate on patients with and without TIPS undergoing glutamine challenge: a double blind, placebo controlled trial. Gut. 2000;47:571-4.

55. Reynolds N, Downie S, Smith K, Kircheis G, Rennie MJ. Treatment with L-ornithine-L-aspartate (LOLA) infusion restores muscle protein synthesis responsiveness to feeding in patients with cirrhosis. J Hepatol. 1999;30(Suppl 1):65.

56. Romero Gomez M, Bautista JD, Grande L, Ramos Guerrero RM, Sanchez Munoz D. New concepts in the physiopathology of hepatic encephalopathy and therapeutic prospects. Gastroenterol Hepatol. 2004;27(Suppl 1):40-8.

57. Rose C, Michalak A, Pannunzio P, Therrien G, Quack G, Kircheis G, Butterworth RF. L-ornithine-L-aspartate in experimental portal-systemic encephalopathy: therapeutic efficacy and mechanism of action. Metab Brain Dis. 1998;13:147-57.

58. Rose C, Michalak A, Rao KV, Quack G, Kircheis G, Butterworth RF. L-ornithineL-aspartate lowers plasma and cerebrospinal fluid ammonia and prevents brain edema in rats with acute liver failure. Hepatology. 1999;30:636-40.

59. Schafer W. Intravenous administration of ornithine aspartate to patients with hepatic diseases. Munch Med Wochenschr. 1968;110:2521-5.

60. Seki S. Study of the treatment of liver damage due to several causes in tuberculosis, using ornithine-aspartate. Iryo. 1966;20:354-63.

61. Shioya A, Kuraishi K, Kakimoto M, Tamama Y. Pharmacological study on L-ornithine L-aspartate. Jpn J Pharmacol. 1964;14:201-14.

62. Sommer H, Unglaub W. Influence of ornithine-aspartate on the increased GOT activity in bovine serum. Berl Munch Tierarztl Wochenschr. 1972;85:123-5.

63. Staedt U, Leweling H, Gladisch R, Kortsik C, Hagmuller E, Holm E. Effects of ornithine aspartate on plasma ammonia and plasma amino acids in patients with cirrhosis. A double-blind, randomized study using a four-fold crossover design. J Hepatol. 1993;19:424-30.

64. Stauch S, Kircheis G, Adler G, Beckh K, Ditschuneit H, Görtelmeyer R, Hendrick R, Heuser A, Karoff C, Malfertheiner P, Mayer D, Rösch W, Steffens J. Oral L-ornithine-L-aspartate therapy of chronic hepatic encephalopathy: results of a placebo-controlled double-blind study. J Hepatol. 1998;28:856-64.

65. Strauven T, Mardens Y, Clara R, Terheggen H. Intravenous loading with argininehydrochloride and ornithine-aspartate in siblings of two families, presenting a familial neurological syndrome associated with cystinuria. Biomedicine. 1976;24 191-9.

66. Szirmai E. Our clinical experience with ornithine aspartate. Minerva Med. 1971;62:2376-82.

67. Tandon BN. Hepatic encephalopathy syndromes. Indian J Gastroenterol 2003;22(Suppl 2):s4-s6.

68. Vogels BA, Karlsen OT, Mass MA, Bovee WM, Chamuleau RA. L-ornithine vs L-ornithine-L-aspartate as a treatment for hyperammonemia-induced encephalopathy in rats. J Hepatol. 1997;26:174-82.

69. Wang Y. Researching progress on prognosis judgment of hepatic failure. Zhonghua Gan Zang Bing Za Zhi. 2002;10:471-3.

70. Wein C, Koch H, Popp B, Oehler G, Schauder P. Minimal hepatic encephalopathy impairs fitness to drive. Hepatology. 2004;39:739-45.

71. Weissenborn K, Tietge UJ, Bokemeyer M, Mohammadi B, Bode U, Manns MP, Caselitz M. Liver transplantation improves hepatic myelopathy: evidence by three cases. Gastroenterology. 2003;124:346-51.

72. Wettstein M, Haussinger D. Hepatic encephalopathy--therapy. Dtsch Med Wochenschr. 2003;128:2658-60.

73. Wotzka R, Weber D. Further clinical experiences with ornithine aspartate in liver diseases. Ther Ggw. 1972;111:400-12.

Recebido em 15/12/2008

Aprovado em 3/3/2009. 